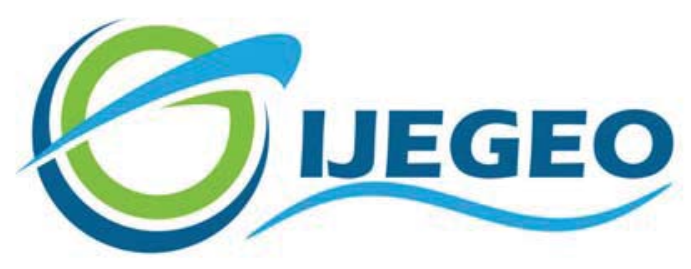

International Journal of Environment and Geoinformatics (IJEGEO) is an international, multidisciplinary, peer reviewed, open access journal.

\title{
Environmental and Socioeconomic Impacts of Irregular Migration in Coastal Areas: A Case Study of Musellim Strait
}

\section{Fatih SEYDİ, Volkan DEMIR, Ayhan SALAR, Cem GAZİOĞLU}

\author{
Chief in Editor
}

Prof. Dr. Cem Gazioğlu

\section{Co-Editors}

Prof. Dr. Dursun Zafer Şeker, Prof. Dr. Şinasi Kaya,

Prof. Dr. Ayşegül Tanık and Assist. Prof. Dr. Volkan Demir

Editorial Committee (December 2021)

Assoc. Prof. Dr. Abdullah Aksu (TR), Assit. Prof. Dr. Uğur Algancı (TR), Prof. Dr. Bedri Alpar (TR), Assoc. Prof. Dr. Aslı Aslan (US), Prof. Dr. Levent Bat (TR), Prof. Dr. Paul Bates (UK), İrşad Bayırhan (TR), Prof. Dr. Bülent Bayram (TR), Prof. Dr. Luis M. Botana (ES), Prof. Dr. Nuray Çağlar (TR), Prof. Dr. Sukanta Dash (IN), Dr. Soofia T. Elias (UK), Prof. Dr. A. Evren Erginal (TR), Assoc. Prof. Dr. Cüneyt Erenoğlu (TR), Dr. Dieter Fritsch (DE), Prof. Dr. Çiğdem Göksel (TR), Prof.Dr. Lena Halounova (CZ), Prof. Dr. Manik Kalubarme (IN), Dr. Hakan Kaya (TR), Assist. Prof. Dr. Serkan Kükrer (TR), Assoc. Prof. Dr. Maged Marghany (MY), Prof. Dr. Michael Meadows (ZA), Prof. Dr. Nebiye Musaoğlu (TR), Prof. Dr. Masafumi Nakagawa (JP), Prof. Dr. Hasan Özdemir (TR), Prof. Dr. Chryssy Potsiou (GR), Prof. Dr. Erol Sarı (TR), Prof. Dr. Maria Paradiso (IT), Prof. Dr. Petros Patias (GR), Prof. Dr. Elif Sertel (TR), Prof. Dr. Nüket Sivri (TR), Prof. Dr. Füsun Balık Şanlı (TR), Prof. Dr. Uğur Şanlı (TR), Duygu Ülker (TR), Prof. Dr. Seyfettin Taş (TR), Assoc. Prof. Dr. Ömer Suat Taşkın (TR), Assist. Prof. Dr. Tuba Ünsal (TR), Dr. Manousos Valyrakis (UK), Dr. İnese Varna (LV), Dr. Petra Visser (NL), Prof. Dr. Selma Ünlü (TR), Assoc. Prof. Dr. Oral Yağcı (TR), Prof. Dr. Murat Yakar (TR), Assoc. Prof. Dr. İ. Noyan Yılmaz (AU); Assit. Prof. Dr. Sibel Zeki (TR) 


\title{
Environmental and Socioeconomic Impacts of Irregular Migration in Coastal Areas: A Case Study of Musellim Strait
}

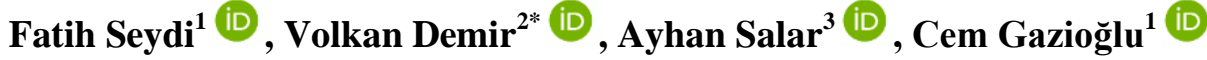 \\ ${ }^{1}$ Istanbul University, Institute of Marine Sciences and Management, Department of Marine Environment, Istanbul,Turkey \\ ${ }^{2}$ University of Kyrenia, Faculty of Maritime Studies, Kyrenia, Northern Cyprus \\ ${ }^{3}$ Istanbul University, Instute of Marine Sciences and Management, Department of Marine Management, Istanbul, Turkey \\ * Corresponding author: V. Demir \\ E-mail: volkan.demir@kyrenia.edu.tr
}

Received 06.06.2021

Accepted 24.11.2021

How to cite: Seydi, et al., (2021). Environmental and Socioeconomic Impacts of Irregular Migration in Coastal Areas: A Case Study of Musellim Strait. International Journal of Environment and Geoinformatics (IJEGEO), 8(4):559-571.doi. 10.30897/ijegeo.1024768

\begin{abstract}
Migration is an act of geographical displacement of human communities due to religious, economic, political, social and other reasons. Migration through illegal means and without a specific systematic is called irregular migration. As Turkey is seen as a destination country by immigrants, it has also been used as a transit country providing transit to developed European countries in recent years. In this study, the socio-economic impacts of irregular migrants leaving our country illegally by sea and the loss they cause to our seas and coasts are examined based on the example of Musellim Strait in the North Aegean, furthermore, the damage they cause to the settlements which have a coast to the Musellim Strait, the sea and coastal nature in the region is investigated in terms of social and ecologically aspects.
\end{abstract}

Keywords: International migration, Irregular migration, environmental impacts

\section{Introduction:}

Migration is the geographical displacement movement of human communities by settling in another habitation unit in order to spend their whole or part of their lives due to religious, economic, political, social and other reasons (Akkayan, 1979). Immigration has become one of the main issues that occupy the agenda of countries throughout the world and in our country in recent years, and it is predicted that this situation will remain an agenda topic in the future. Immigration is a broad and comprehensive concept that has social, economic and ecological impacts on the country of origin, transit country (countries) and destination countries that provide and enable migration traffic. The effects of migration are investigated in scientific studies in the political, economic and ecological fields in transit and destination countries. This escalation in migration movements also requires new measures and security policies in terms of internal security and border security in transit and destination countries in particular. In these countries, it not only causes many socioeconomic victimization and security threats, but also provides legal and illegal employment possibilities to many people in terms of economy (Ülker et al., 2018; Macionis, 2012; Düvell and Vollmer, 2009; Çağlayan, 2008; Thorns, 2004). For example, in Turkey, which is a transit country, hotels and hostels where immigrants stay for a short time legally benefit from the migration movement, while migrant smugglers who allow immigrants to leave the country illegally by sea, acquire illegally and unlawfully. Turkey is the transit country for immigrants who want to immigrate to EU countries, while
EU countries with strong economies are destination countries for immigrants. The aim of this study is to examine the damage caused by the immigrants in Turkey, which is a transit country, to the settlements that have a coast to the Musellim Strait, and to the sea and coastal nature in the region, while using the Musellim Strait by sea vessels, and to create a resource for the measures to be taken. As long as the migration movements in the region continue, it is inevitable that the socio-economic and environmental effects of migration will cause great damage to the region in the long run. In this context, the first priority is to protect our seas and coasts by dint of the policies determined in the fight against irregular migration. It is aimed to provide data for national and international organizations, especially government officials, to follow a more consistent and effective policy against irregular migration that will minimize or even eliminate the damage caused by irregular migrants to the region.

\section{Turkey and Immigration}

Between the years of 1923-1950, when the nation-state building of the young Turkish Republic, which was established after the War of Independence, was continued the first international migration movement witnessed was comprised of scientists, artists and intellectuals fleeing the Nazis. Similarly, Turkey has become one of the main countries to seek refuge for around 100,000 Jews fleeing the Nazi regime in Eastern Europe to settle in Palestine and Israel (Ertekin, 2008). These migration waves, which took place in the first years of the republic, can be 
considered among the migrations that had a positive effect on our country in terms of the history of the republic. The Soviet Union, which disintegrated following the end of the Cold War, left behind independent countries whose economies were turned upside down. It has been determined that the citizens of these countries preferred to find a job in Turkey, especially the women who could not find a job in their home country, mostly preferred Turkey in the early days (Guven-Lisaniler, Rodriguez, and Uğural, 2005). The flexible visa policies, which were put forward to encourage tourism by emphasizing purely economic concerns, also lagged behind from preventing the influx to Turkey. Although wealthy European citizens were targeted as tourists with these tourism policies, the route of tourism has turned to tourists from Russia, Ukraine, Moldova, Romania, Bulgaria, Azerbaijan, Belarus, Uzbekistan, Turkmenistan, and Armenia, especially from former Eastern Bloc Countries. This situation, on the other hand, turned into a problem of "foreigners who earn income due to reasons such as prostitution, illegal and unauthorized work" rather than the income to be obtained from tourism, resulting in foreign exchange outflow from the country together with the social and economic destruction in Turkey (Sever, 2013; Akgün, 2011).

Irregular migration activities, which started to increase in recent years as a result of the events that started in Syria in 2011, especially among the citizens of Afghanistan, reached its highest level since the Second World War in 2015, with the inclusion of citizens from other countries to Syrian irregular migrants. For example, while a total of 14,691 irregular migrants were seized by the Coast Guard Command in 2014, the number of irregular migrants seized in 2015 was 91,611. Again in 2015, it was observed that the majority of irregular migration events took place in the Aegean Sea. The number of irregular migrants seized, which demonstrated a fluctuating graphic until 2020, decreased to 20,380, following the average downward trend (Fig.1). While the total number of irregular migrants was 146,485 in 2015 , it ramped down from a major escalation in 2019 to 122,302 in 2020 (TCGC, 2021) (Fig.2).

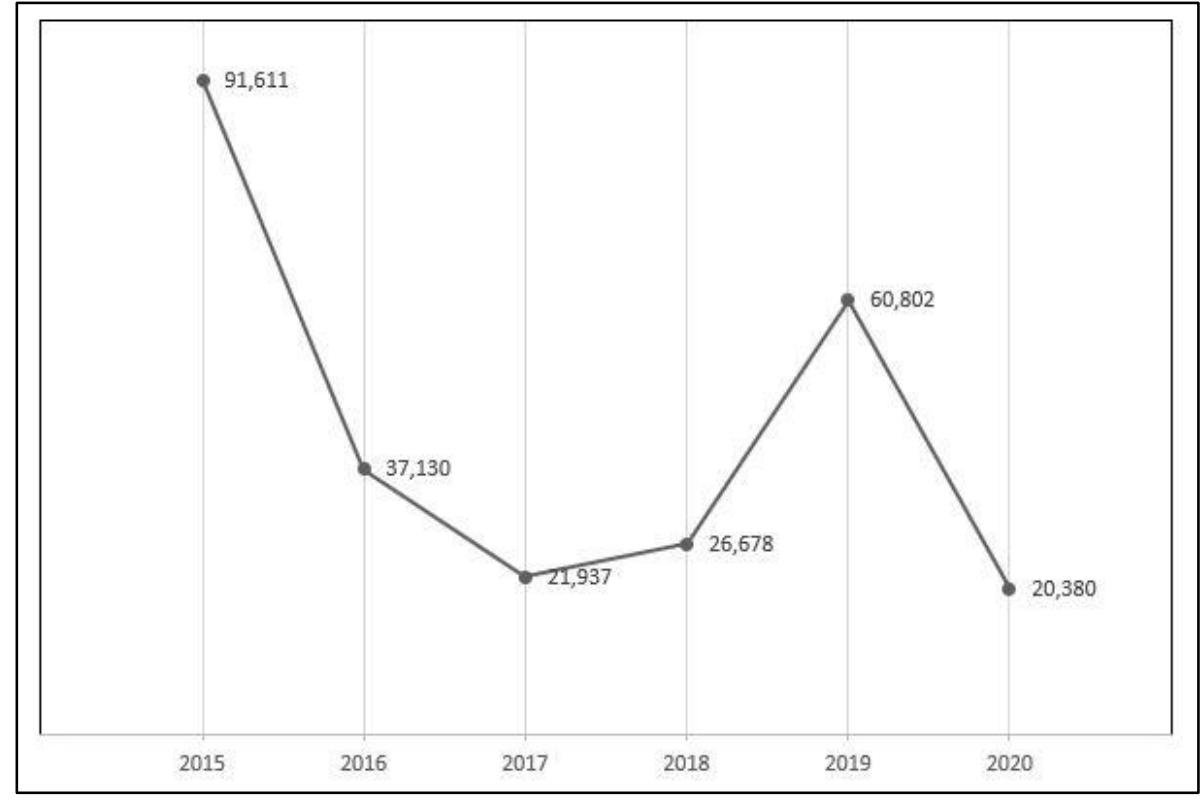

Fig. 1. Total number of irregular migrants seized between 2015-2020. 


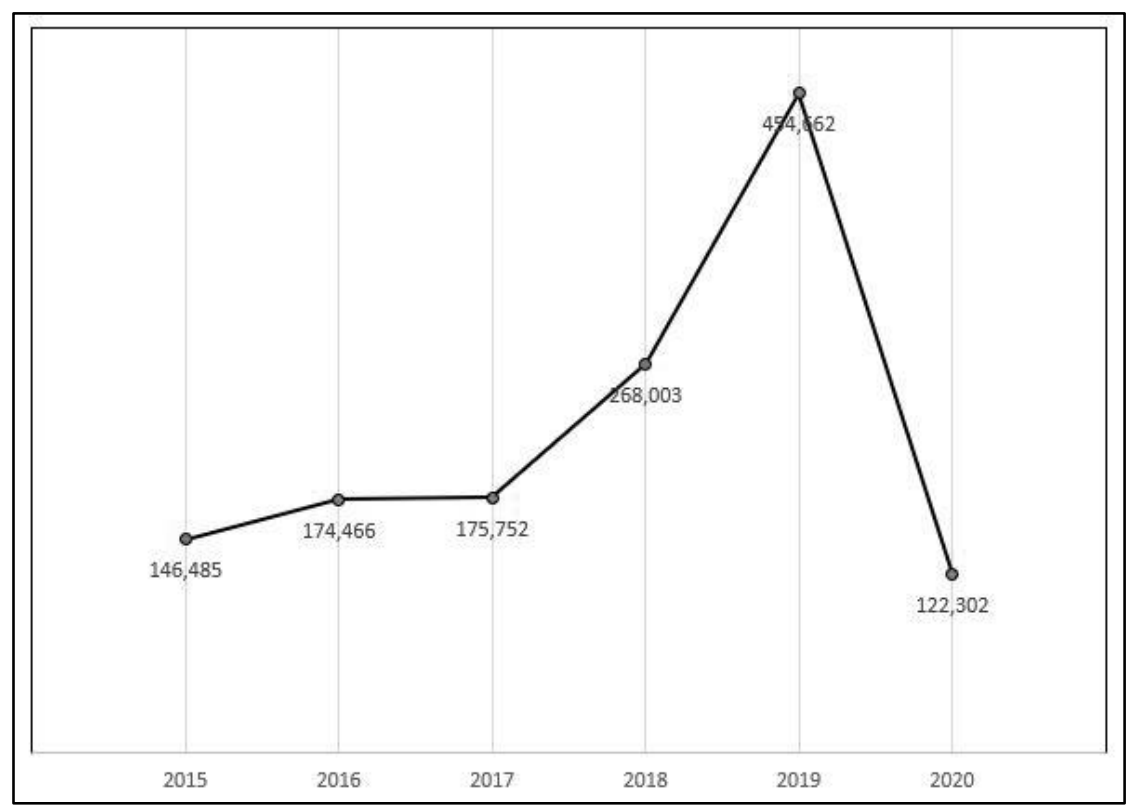

Fig. 2. Total number of irregular migrants between 2015-2020.

Irregular migration activities, which started to increase in recent years as a result of the events that started in Syria in 2011, especially among the citizens of Afghanistan, reached its highest level since the Second World War in 2015 , with the inclusion of citizens from other countries to Syrian irregular migrants. For example, while a total of 14,691 irregular migrants were seized by the Coast Guard Command in 2014, the number of irregular migrants seized in 2015 was 91,611. Again in 2015, it was observed that the majority of irregular migration events took place in the Aegean Sea. The number of irregular migrants seized, which demonstrated a fluctuating graphic until 2020, decreased to 20,380, following the average downward trend (Fig.1). While the total number of irregular migrants was 146,485 in 2015 , it ramped down from a major escalation in 2019 to 122,302 in 2020 (TCGC, 2021) (Fig.2).

With the Strategy Document and National Action Plan for Combating Irregular Migration covering the years 20152018, strategic targets have been determined in our country's fight against irregular migration and studies have been carried out to implement them. As of the end of this period, the Strategy Document and National Action Plan for Combating Irregular Migration covering the years 2021-2025 were prepared and put into effect. With respect to this action plan;

- Strengthening National and International Mechanisms and Cooperation to Prevent Irregular Migration at Source,

- Increasing Border Security and Developing Measures to Combat Irregular Migration

- Managing Foreign Labor Migration with Effective and Comprehensive Policies
- Conducting Domestic Transactions Regarding Irregular Migrants with a Focus on Human Rights, Increasing the Efforts for the Protection of Vulnerable Irregular Migrants and Producing Evidence-Based Policies in Combating Irregular Migration

- $\quad$ Strategic priorities of Strengthening the System of Repatriation of Irregular Migrants within the Framework of Human Rights Standards and ensuring their reintegration have been determined, and it is aimed to implement these strategic priorities in line with the contributions of all public institutions and organizations and non-governmental organizations involved in the fight against irregular migration.

Along with the National Action Plan, the Department for Combating Irregular Migration was established with the Presidential Decree No. 4 published on 15.07.2018 in order to increase the effectiveness of combating irregular migration.

Irregular Migration Analysis in Turkey In 2015-2016

It has been observed that attempts to go abroad from Turkey by sea continued in 2016 as well. In 2016, a total of 37,130 irregular migrants were seized in 833 incidents that took place in order to go abroad illegally by sea. It has been determined that these attempts took place mainly in the Aegean Sea, as in previous years.

\section{Arrestation Locations (2015-2016)}

If we examine the distribution of irregular migration events with respect to the seas in 2015-2016, it is seen that the Aegean Sea is the region where irregular migration events are most common due to its 
geographical location. In 2016, there was a significant decrease in irregular migration incidents in the Aegean Sea. It is considered that the biggest factor in the decrease in this number is the readmission agreement signed between Turkey and the European Union on 18 March 2016 within the scope of migration deal. While it is considered that the Mediterranean Sea was affected by the readmission agreement, a slight increase in irregular migration incidents was observed in the Marmara Sea. It is considered that the main reason for this is the attempts of immigrants to escape from the Marmara Sea with large boats due to the increased security measures in the Aegean and Mediterranean.

In 2015, the majority of irregular migration incidents occurred in Bodrum, Ayvacık, Çeşme, Didim districts; in
2016, it was determined that the highest number of irregular migration events occurred in Dikili, Çeşme, Bodrum and Didim districts, and a significant decrease was observed in Bodrum and Ayvacık districts.

It is considered that the reason for the decrease in 2016 is the measures taken by the Gendarmerie General Command and the General Directorate of Security on land in Ayvacık and Bodrum districts, in addition to the activities of the Coast Guard Command. At this point, the contribution of the measures taken on land in the fight against irregular migration activities by sea comes to the fore. Moreover, it is evaluated that some of the irregular migrants think that they can pass from Bodrum and Dikili districts to the Greek islands more easily and in a short time.

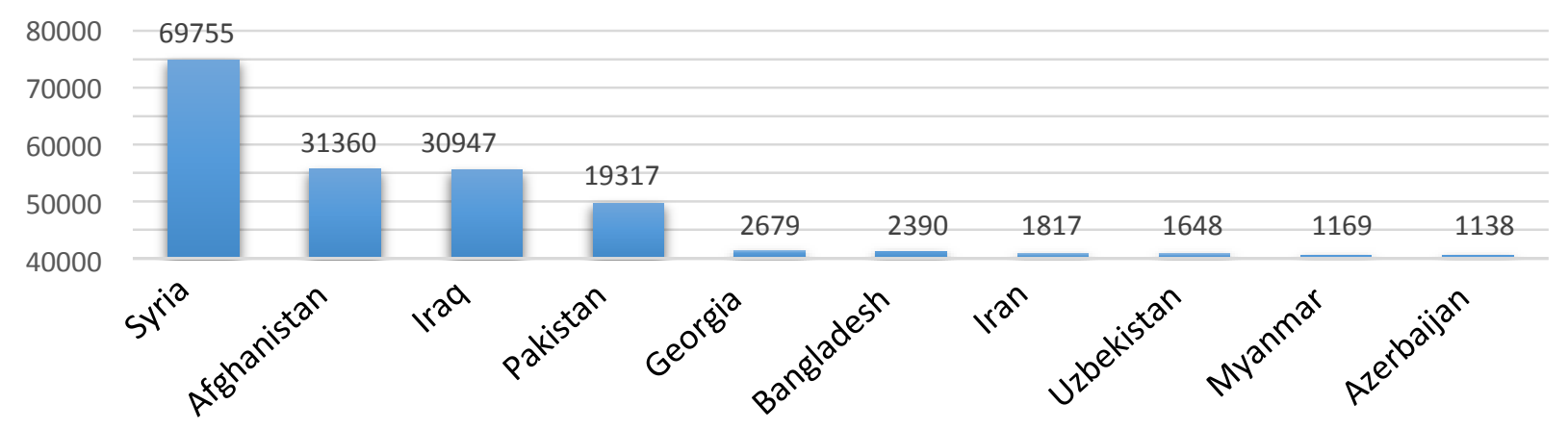

Fig. 3: All irregular immigrants seized in Turkey in 2016 (Top 10 Countries)

\section{Vehicles Used}

When the distribution and change of vehicles used in irregular migration incidents that occurred in 2015 and 2016 are examined, it is seen that irregular migrants prefer dinghies the most. Dinghies made out of rubber are followed by private boats, fishing boats, merchant ships and yachts.

It is considered that the reason for the increased use of dinghies by irregular migrants is that they are easy to obtain, cheap and easy to transport on land. Furthermore, the proximity of the Aegean islands to the shores of our country increases the usability of dinghies.

\section{Nationalities}

When all of the irregular migrants seized in Turkey in 2016 were examined, it was 174,466 with an increase of $19 \%$ compared to 2015 . The number of irregular migrants seized and captured from 2005 to the end of 2016 is 817,863 . When Figure 3 is examined, Syrian citizens are placed on the top with 69,755 people, Afghanistan citizens rank in the second place with 31,360 people, and Iraqi citizens rank in the third place with 30,947 people (PMM 2021).

\section{Deceased/Alive Status}

When the distribution and change of irregular immigrants detected in the irregular migration incidents that occurred in 2015 and 2016 according to the status of being dead or alive are examined, 279 irregular immigrants were identified as "dead", 91,611 irregular immigrants were identified as "alive" in 2015, and 192 irregular immigrants were identified as "dead" in 2016. It can be seen in Table 1 that 37,130 irregular migrants were identified as "alive".

\section{Featured Points to Consider During the Period in the} Scope of Irregular Migration by Way of Sea

A new method used by irregular migrants during the period attracted attention. Irregular immigrants, who sailed unnoticed at night in the previous period, started to sail at the same time, both during day and night, with a large number of inflatable rubber zodiac during this period. In this manner, while the Turkish and Greek law enforcement officers are busy with the captured, the others manage to reach the other side. Other boats can reach the other side, taking advantage of the fact that the authorized law enforcement elements at sea give priority to immigrants in distress at sea, especially in activities that require search and rescue. According to this method, it is evaluated that some boats are deliberately detonated, facilitating the passage of other boats while the Coast Guard performs search and rescue activities. 
Table 1: Condition of deceased/alive of irregular immigrants (2015-2016) (TCGC, 2021)

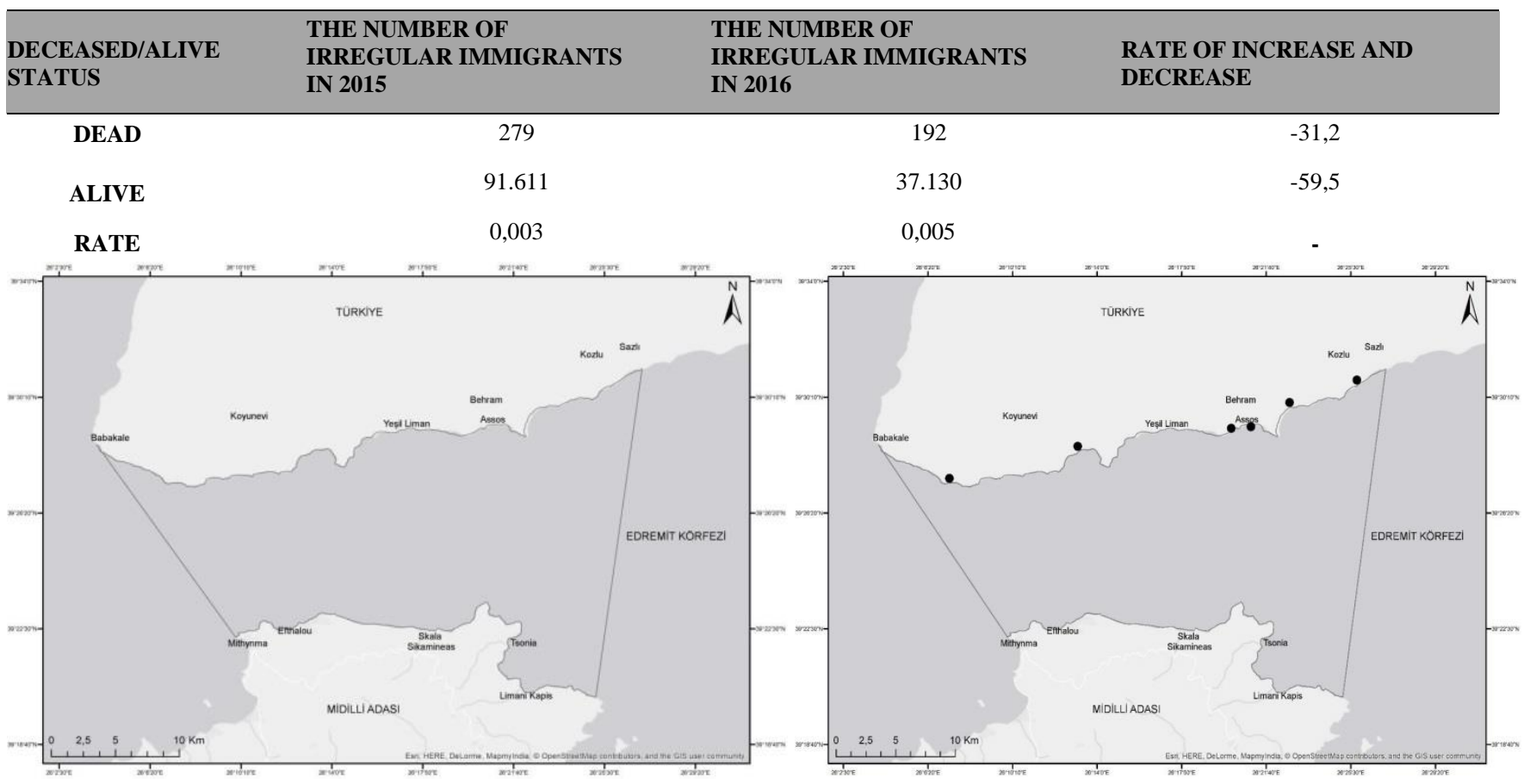

Fig. 4. Study Area (Musellim Strait)

Fig. 5. Frequently Preferred Departure Points in

\section{Featured Points to Consider During the Period in the Scope of Irregular Migration by Way of Sea}

A new method used by irregular migrants during the period attracted attention. Irregular immigrants, who sailed unnoticed at night in the previous period, started to sail at the same time, both during day and night, with a large number of inflatable rubber zodiac during this period. In this manner, while the Turkish and Greek law enforcement officers are busy with the captured, the others manage to reach the other side. Other boats can reach the other side, taking advantage of the fact that the authorized law enforcement elements at sea give priority to immigrants in distress at sea, especially in activities that require search and rescue. According to this method, it is evaluated that some boats are deliberately detonated, facilitating the passage of other boats while the Coast Guard performs search and rescue activities.

Irregular migration activities, which demonstrated a significant increase in 2015, caused European countries and EU institutions/organizations to generate new policies in this regard, and the citizens of European countries to assume negative attitudes towards Muslim irregular migrants. These negative approaches of European countries are criticized by certain international organizations. According to a report published by Amnesty International, it was stated that Europe's moves to prevent refugees from accessing asylum are pushing refugees into ill-treatment and dangerous sea voyages that controlling entry into the $\mathrm{EU}$ is reasonable and legitimate, but barring all refugees is inhuman and illegal.

In 2015, within the scope of Frontex (The European Border and Coast Guard Agency), 24 constituents from 16 different countries, two of which belong to nongovernmental organizations, served in the Aegean Sea. The countries that assigned the highest number of constituents to Frontex activities were Sweden and Latvia, with three assignments each. These countries were followed by Croatia and the Netherlands with two assignments each. Frontex constituents were mostly detected in Chios, whereas Samos and Lesbos Islands were other regions where Frontex constituents carried out their activities. A civilian ship named Topaz Responder, with the Marshall Islands flag, also participated in the activities. This ship is used by a philanthropist named Christopher Catrambone, a US citizen, and by the organization called the Migration Offshore Aid Station (MOAS), which was established in Malta in 2013, influenced by the irregular migration incidents in Lampedusa Island, Italy. A German flagged civilian boat named Sea Watch, which belongs to a charity organization called Sea Watch, which was founded in 2000 by three German businessmen, also participated in the activities. The boat in question has been operating between Turkey and Lesbos since November 2015.

In 2015, reports on irregular migration were published by many international institutions/organizations, especially Frontex, and it was mentioned in these reports that more 
than 850,000 irregular migrants crossed into Europe, most of them through our country. However, it is considered that this number is due to the fact that irregular migrants are counted repeatedly in all countries from which they enter Greece to their destination country, and some studies and research supporting this assessment are also carried out in European countries. In

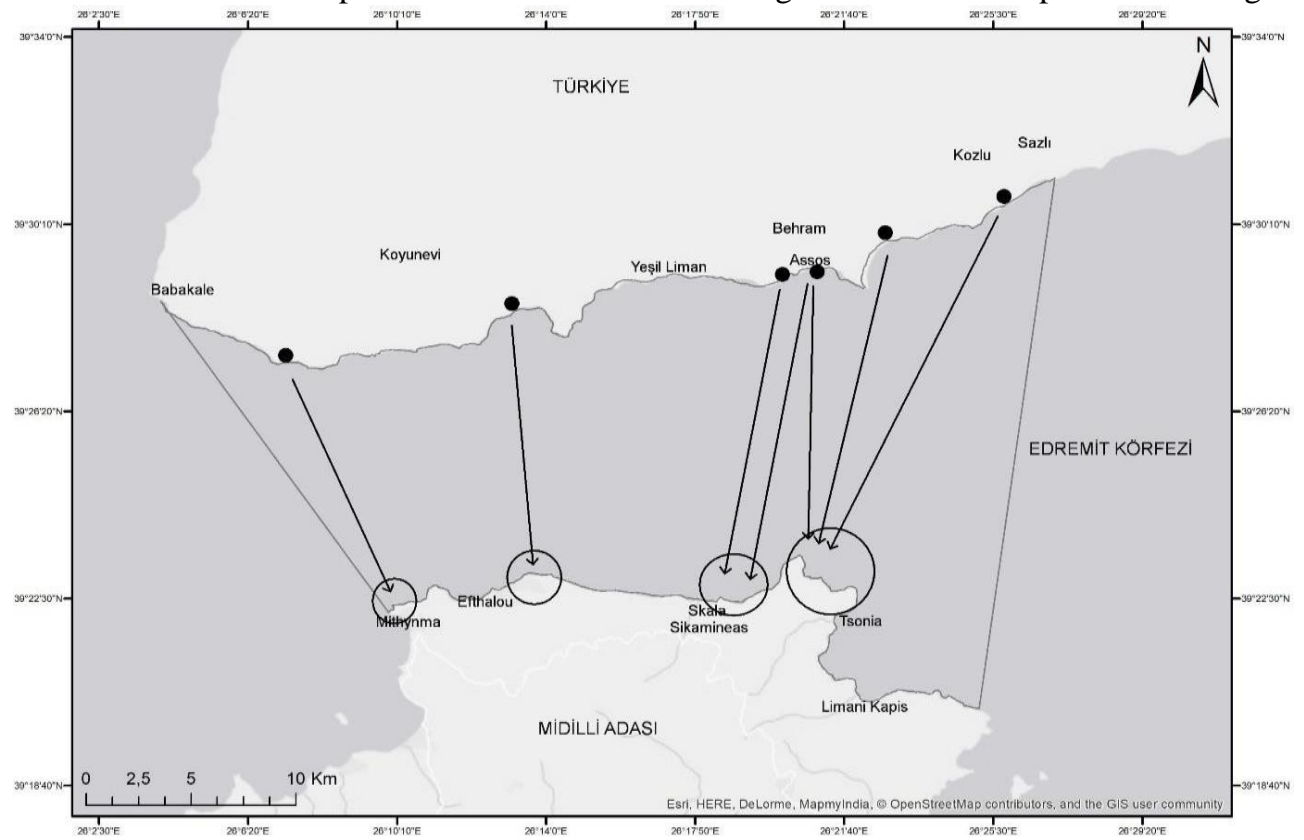

Fig. 6. Immigrant Boats' Route and Estimated Arrival Areas

\section{Materials and Methods}

Musellim Strait encompasses the maritime zone between Ayvacık district of Çanakkale and Lesbos Island of Greece in the North Aegean, 27 nautical miles long and 5 nautical miles wide on average, starting from Cape Baba (Cape Lekton) in the west to Küçükkuyu Fisherman's Sanctuary in the east (Fig. 4). Musellim Strait is one of the most preferred regions of irregular immigrants who want to migrate through Turkey due to its geographical features such as being sheltered against effective northerly winds in the North Aegean and being close to Lesbos Island (Katsanevakis, 2015). During the study, it was aimed to collect data from the region from Sazlı to Babakale and from the nearby Lesbos coast. Although the irregularity of the crossings and the actions of immigrants makes it difficult to work periodically, the polluted areas and the pollutants on the sea surface have been collected and recorded

Irregular migrant activity, which is mostly seen in the Aegean Sea, begins with the arrival of migrants to the coastal area in the vicinity of the island of Lesbos, which is close to the Turkish coast. Unless the weather conditions are unfavorable, the action of crossing to the opposite shore takes place in the coastal region on the Turkish side without losing too much time. Although it is this context, in the event that these numbers come to the fore at the meetings held with international institutions/organizations, especially Frontex, it is considered that it would be beneficial not to underestimate our country's efforts in combating immigration, to express the thoughts that the high level of figures are due to duplicate counting. 
It has been determined that when the immigrants reach the shore, they leave their weight-bearing items on the shore while they take long distances to the police stations where they will surrender and be recorded. In addition to these, the materials they used during the transit trip are left in the coastal area.

\section{Coastal Marine Litter Survey}

Garbage and litter inventory studies carried out in coastal areas give important results in the follow-up of the garbage load in the marine environment. Garbage surveys, which are easily and inexpensively conducted one by one in the specified region, are the most widely used marine litter pollution detection studies in the world (Galgani et al., 2011).

A garbage inventory study was carried out in an area of 100x8 m along the coast in February 2016 and August 2016 at two stations on the Turkish coast of the Musellim strait. The counted garbage was classified according to the level of relevance to the immigrants and their weights were measured. The litter encountered in these two periods at sea was recorded and mapped with the ArcGIS program which is Geographical Information System software.

\section{Results}

Crossings take place frequently in the summer months at Muselllim Strait, and it has been determined that they make illegal crossings throughout the year. The regions where the immigrants mostly leave are Hiyarlık Cape, Sivrice Cape, Çam Cape, Kadırga Cape and Küçükkuyu Region, and it has been observed that they exit from anywhere close to the highway along the coast.

Irregular migrants reach the departure points on the coast by using the highway by buses and minibuses, accompanied by migrant smugglers called organizers. The zodiac boats to be used for the crossing are inflated when they reach the shore and it has been determined that the organizers have prepared them by adding the outboard engine. Irregular immigrants are trying to cross the sea in groups of 50-80 by zodiac boats where only $15-20$ people can safely cruise under normal conditions by force of the organizers (sometimes at gunpoint) as we have learned from our research and in parallel with the immigrants' statements.

It has been determined that irregular migrants generally cross the sea at night close to sunrise. The main reasons for this act are that sensible citizens from land and sea report relatively less during that time of the day due to the fact that they are fast asleep, the gendarmerie and coast guard, the law enforcement officers, do infrequent inspection at those hours, or the smugglers think that irregular and infrequent inspections are carried out, and the sea is calmer at those hours for the success of the destined crossing.

Irregular migrants are retrieved from the sea after being rescued or while floating on the water with the zodiac boat semi-submerged. If the semi-submerged boats, which are seen extensively in the region, are not collected from the sea, they sink to the bottom of the sea and cause longterm pollution. It has been determined that there were more than a hundred zodiac boats and outboard engines that sank in this way in Musellim Strait.

The first priority of law enforcement and civil organizations combatting irregular migration in our seas is to save irregular migrants alive. In cases of irregular migration, these institutions collect the waste left by the immigrants from the sea within their means and take measures against sea pollution.

It has been observed that most of the junk items that were scattered from a sunken irregular migrant boat during irregular migrant activities were not collected promptly, and many of them sank to the seabed. During the study, the litter encountered on the sea surface was recorded and a density determination map was drawn (Fig. 7).

\section{Coastal Area Marine Litter Survey Results}

In the Musellim Strait, a garbage inventory study was carried out in two coastal areas specified in February 2016. Areas in Assos and Kadirga bays were specified based on the points determined during the interventions and the intensity of the pollution mapped on the sea surface and based on the regions most preferred by the immigrants in the coastal areas. In the study carried out in the designated bays, the garbage found in an area of $100 \times 8 \mathrm{~m}$ was counted and categorized. By evaluating the possibility of disposal of the categorized garbage by immigrants, the most traditional determination studies were carried out. According to the results, approximately $676 \mathrm{~kg}$ of garbage was detected in the Assos region in February. It is considered that $96.1 \%$ of the garbage belongs directly to the immigrants. Because of the data obtained in the study conducted in the Kadirga bay, approximately $653 \mathrm{~kg}$ of garbage was determined. It was determined that $96.7 \%$ of the garbage directly belonged to the immigrants (Table 2). 


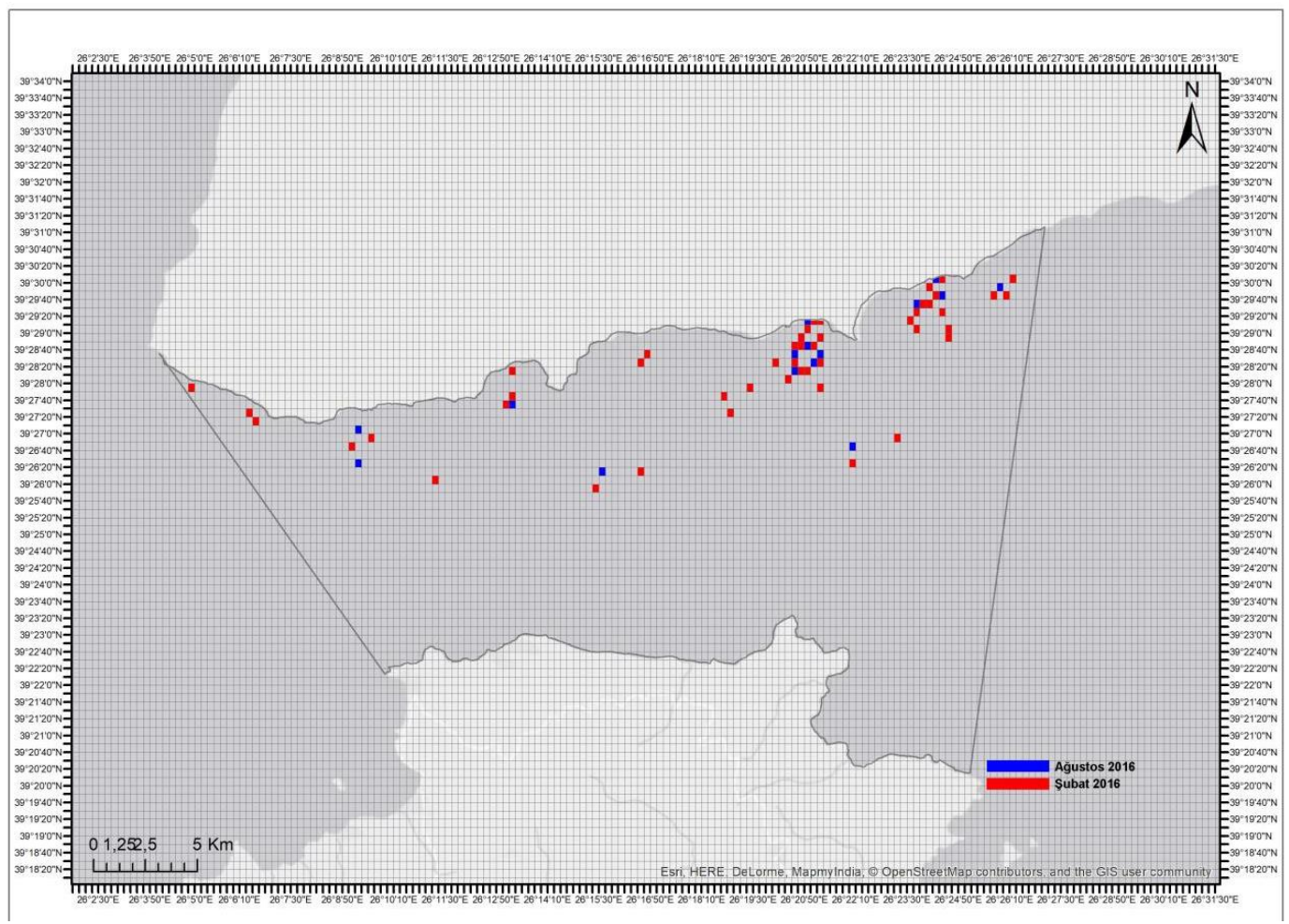

Figure 7. Areas Where Marine Litter is Seen During the Working Period (300x300m)

Table 2. Garbage Inventory in the Musellim Strait Coastal Area (February 2016)

February 2016

\begin{tabular}{|l|l|l|l|}
\hline \multicolumn{2}{|c|}{ ASSOS (100 x $8 \mathrm{~m})$} & \multicolumn{2}{c|}{ KADIRGA BAY (100 x 8 m) } \\
\hline $\begin{array}{l}\text { NUMBER OF } \\
\text { ITEMS }\end{array}$ & $\begin{array}{l}\text { ESTIMATED } \\
\text { WEIGHT (KG) }\end{array}$ & $\begin{array}{l}\text { NUMBER OF } \\
\text { ITEMS }\end{array}$ & $\begin{array}{l}\text { ESTIMATED } \\
\text { WEIGHT (KG) }\end{array}$ \\
\hline
\end{tabular}

GARBAGE DIRECTLY RELATED TO IRREGULAR IMMIGRANTS

\begin{tabular}{|c|c|c|c|c|}
\hline $\begin{array}{l}\text { INFLATABLE ZODIAC BOAT } \\
\text { (WHOLE) }\end{array}$ & 4 & 488.00 & 3 & 366.00 \\
\hline INFLATABLE ZODIAC BOAT (PART) & 3 & 102.00 & 7 & 238.00 \\
\hline \begin{tabular}{|l|l|} 
LIFE JACKET (WHOLE) \\
\end{tabular} & 105 & 56.83 & 21 & 11.37 \\
\hline LIFE JACKET (PART) & 13 & 0.59 & 18 & 0.81 \\
\hline LIFE BUOY (TUBE) & 5 & 3.10 & 9 & 5.58 \\
\hline FUEL CAN & - & - & 2 & 9.08 \\
\hline FUEL HOSE & - & - & 2 & 1.30 \\
\hline QUANTITY & 130 & 650.52 & 62 & 632,14 \\
\hline PERCENTAGE & 45.1 & 96.1 & 35.8 & 96.7 \\
\hline \multicolumn{5}{|c|}{ GARBAGE POSSIBLY RELATED TO IRREGULAR IMMIGRANTS } \\
\hline CLOTHES & 13 & 3.94 & 9 & 2.73 \\
\hline BACKPACK & 5 & 6.07 & 3 & 3.64 \\
\hline SHOES & 4 & 1.24 & 6 & 1.86 \\
\hline QUANTITY & 18 & 11.25 & 18 & 8.23 \\
\hline PERCENTAGE & 6.2 & 1.7 & 10.4 & 1.2 \\
\hline
\end{tabular}


Seydi et al., / IJEGEO 8(4): 559-571 (2021)

\begin{tabular}{|c|c|c|c|c|}
\hline \multicolumn{5}{|c|}{ GARBAGE POSSIBLY NOT RELATED TO IRREGULAR IMMIGRANTS } \\
\hline PLASTIC BOTTLE & 31 & 0.93 & 25 & 0.75 \\
\hline PLASTIC CONTAINER & 6 & 0.01 & 3 & 0.00 \\
\hline PLASTIC BAG (WHOLE) & 10 & 0.09 & 7 & 0.06 \\
\hline PLASTIC BAG (PART) & 15 & 0.05 & 13 & 0.04 \\
\hline PLASTIC TUBE & - & - & 1 & 0.08 \\
\hline MANILA ROPE & 3 & 0.33 & 5 & 0.60 \\
\hline FISHLINE & 2 & 0.05 & 6 & 0.08 \\
\hline STYROFOAM & 15 & 0.07 & 3 & 0.01 \\
\hline PLASTIC BALLOON & 3 & 0.03 & 6 & 0.06 \\
\hline DIAPER & 7 & 0.32 & - & - \\
\hline $\begin{array}{l}\begin{array}{l}\text { OTHER PLASTIC SUBSTANCES } \\
\text { (BIG) }\end{array} \\
\end{array}$ & 6 & 3.15 & 5 & 2.62 \\
\hline $\begin{array}{l}\text { OTHER PLASTIC SUBSTANCES } \\
\text { (SMALL) }\end{array}$ & 9 & 0.04 & 5 & 0.02 \\
\hline ALUMINIUM CAN & 3 & 0.04 & - & - \\
\hline CIGARETTE BOX & 12 & 0.01 & 10 & 0.01 \\
\hline CARDBOARD BOX & 3 & 0.08 & 3 & 0.08 \\
\hline OTHER PAPER/CARDBOARD & 5 & 0.05 & 4 & 0.04 \\
\hline WOODEN SUBSTANCE & 7 & 9.13 & 6 & 8.42 \\
\hline OTHER & 3 & 0.58 & 4 & 0.72 \\
\hline QUANTITY & 140 & 14.96 & 93 & 13.59 \\
\hline PERCENTAGE & 48.7 & 2.2 & 53.8 & 2.1 \\
\hline TOTAL & 288 & 676.73 & 173 & 653.96 \\
\hline
\end{tabular}

With the Readmission/Repatriation Agreement signed on 18 March 2016, and NATO and Naval Forces ships starting to take charge in the region, the migration of immigrants has been brought under control to a great extent. Since the control of irregular migrant movements will result in fully integrated approaches, measures to be taken only from the sea were not sufficient, but in the survey study conducted in August 2016, it was determined that the garbage decreased and it was observed that the efforts paid off visibly. According to the results, approximately $300 \mathrm{~kg}$ of garbage was detected in the Assos region. It is considered that $94.1 \%$ of the garbage belongs directly to the immigrants. As a result of the data obtained in the study conducted in the Kadirga bay, approximately $214 \mathrm{~kg}$ of garbage was determined. It was determined that $93.9 \%$ of the garbage directly belonged to the immigrants (Table 3).

Table 3. Garbage Inventory in the Musellim Strait Coastal Area (August 2016)

\begin{tabular}{|c|c|c|c|c|}
\hline \multirow[t]{2}{*}{ August 2016} & \multicolumn{2}{|l|}{$\operatorname{ASSOS}(100 \times \mathbf{x} 8 \mathrm{~m})$} & \multicolumn{2}{|c|}{ KADIRGA BAY (100 x 8 m) } \\
\hline & NUMBER OF ITEMS & $\begin{array}{l}\text { ESTIMATED WEIGHT } \\
\text { (KG) }\end{array}$ & NUMBER OF ITEMS & $\begin{array}{l}\text { ESTIMATED WEIGHT } \\
\text { (KG) }\end{array}$ \\
\hline \multicolumn{5}{|c|}{ GARBAGE DIRECTLY RELATED TO IRREGULAR MIGRANTS } \\
\hline$\sqrt{\text { INFLATABLE ZODIAC BOAT (WHOLE) }}$ & 2 & 244.00 & 1 & 122.00 \\
\hline INFLATABLE ZODIAC BOAT (PART) & 1 & 34.00 & 2 & 70.00 \\
\hline LIFE JACKET (WHOLE) & 10 & 5.41 & 6 & 3.15 \\
\hline Clife jacket(PART) & 3 & 0.14 & 5 & 0.25 \\
\hline LIFE BUOY (TUBE) & 2 & 1.24 & 1 & 0.64 \\
\hline FUEL CAN & - & & 1 & 4.51 \\
\hline FUEL HOSE & $\mid$ & & 1 & 0.65 \\
\hline QUANTITY & 18 & 284.79 & 17 & 201.2 \\
\hline PERCENTAGE & 17.1 & 94.9 & 18.7 & 93.9 \\
\hline
\end{tabular}


Seydi et al., / IJEGEO 8(4): 559-571 (2021)

GARBAGE POSSIBLY RELATED TO IRREGULAR IMMIGRANTS

\begin{tabular}{|l|l|l|l|l|}
\hline CLOTHES & 2 & 0.82 & 2 & 0.81 \\
\hline BACKPACK & - & - & 1 & 1.05 \\
\hline SHOES & 1 & 0.30 & 1 & 0.35 \\
\hline QUANTITY & 3 & 1,12 & 4 & 2.21 \\
PERCENTAGE & 2.9 & 0.4 & 4.4 & 1 \\
\hline
\end{tabular}

\begin{tabular}{|c|c|c|c|c|}
\hline \multicolumn{5}{|c|}{ GARBAGE POSSIBLY NOT RELATED TO IRREGULAR IMMIGRANTS } \\
\hline PLASTIC BOTTLE & 5 & 0.15 & 11 & 0.35 \\
\hline PLASTIC CONTAINER & - & - & 5 & 0.01 \\
\hline PLASTIC BAG (WHOLE) & 2 & 0.01 & 3 & 0.03 \\
\hline PLASTIC BAG (PART) & 5 & 0.02 & 10 & 0.03 \\
\hline PLASTIC TUBE & - & - & 1 & 0.08 \\
\hline MANILA ROPE & 1 & 0.11 & 2 & 0.20 \\
\hline FISHLINE & 5 & 0.02 & 3 & 0.01 \\
\hline STYROFOAM & 10 & 0.05 & 6 & 0.02 \\
\hline PLASTIC BALLOON & 3 & 0.03 & - & - \\
\hline DIAPER & 2 & 0.10 & - & - \\
\hline OTHER PLASTIC SUBSTANCES (BIG) & 5 & 2.85 & 3 & 1.88 \\
\hline OTHER PLASTIC SUBSTANCES (SMALL) & 5 & 0.02 & 4 & 0.02 \\
\hline ALUMINIUM CAN & 3 & 0.04 & - & - \\
\hline CIGARETTE BOX & 10 & 0.01 & 7 & 0.01 \\
\hline CARDBOARD BOX & 4 & 0.10 & 3 & 0.08 \\
\hline OTHER PAPER/CARDBOARD & 5 & 0.05 & 2 & 0.02 \\
\hline WOOD SUBSTANCE & 12 & 9.82 & 5 & 7.22 \\
\hline OTHER & 4 & 0.70 & 5 & 0.80 \\
\hline QUANTITY & 84 & 14.08 & 70 & 10.76 \\
\hline PERCENTAGE & 80 & 4.7 & 76.9 & 5 \\
\hline TOTAL & 105 & 299.99 & 91 & 214.17 \\
\hline
\end{tabular}


Table 4. Irregular Migrant Boat Marine Litter Load

$\begin{array}{llll}\text { POLLUTANT } & \text { QUANTITY } & \text { UNIT } & \text { ESTIMATED WEIGHT KG: } \\ \text { INFLATABLE ZODIAC BOAT } & 1 & \text { ITEM } & 120 \\ \text { OUTBOARD MOTOR(5-10HP) } & 1 & \text { ITEM } & 20 \\ \text { FUEL CAN } & 1 & \text { ITEM } & 3 \\ \text { METAL SHOVEL } & 2 & \text { ITEM } & 20 \\ \text { GASOLINE } & 20 & \text { LITERS } & 25 \\ \text { LIFE JACKET (CAPOC TYPE) } & 50 & \text { ITEM } & 60 \\ \text { LIFE BUOY (TUBE) } & 20 & \text { ITEM } & 250 \\ \text { BACKPACK (PERSONAL BELONGINGS) } & 50 & \text { ITEM } & \mathbf{5 0 1}\end{array}$

Throughout the study, the marine litter load of an irregular migrant movement was tried to be calculated with as precise approaches as possible, according to this, the materials found in a boat were classified and recorded (Table 4).

The number of immigrants caught in the boats encountered in the study was determined as 50-80 people. When the boats with the persons and the materials that will later become garbage belonging to certain immigrants are calculated on the basis of weight, the minimum values are taken and the result is $10 \mathrm{~kg}$ of potential garbage per person. In this context, there is a possibility that an irregular sea migrant will leave $10 \mathrm{~kg}$ of potential garbage to nature. This figure reaches serious dimensions when the number of immigrants is calculated. The numbers are increasing with the low-scaled sanctions and the repeated attempts of immigrants as a result of the insistence of the immigrants.

\section{Discussion and Conclusion}

Migration from any place in the world to any other destined place can be effective in experiencing some changes in the organization of urban space. Urban ecology, which includes studies on sustainable management and settlement in cities, is the planning and design of urban growth with an ecological approach. Cities with a wide range of human ecosystems should have a settlement style suitable for physical space conditions (Gülersoy, Çelik, and Sönmez, 2014). In this respect, migrations towards cities have a significant impact on the settlement pattern of the city.

Irregular migrants at Musellim Strait usually use outboard zodiac boats to reach Lesbos Island. When the crossing is unsuccessful, these rubber zodiac boats sink with the weight of the engine attached to the back of them and cause pollution that will continue for years on the seabed, since they have a decay time of 400 to 600 years depending on the material used. In an unsuccessful crossing, the life jackets, inflatable life buoys and generally the belongings of the immigrants in their backpacks also stay on the water, some of the swimmers hit the beach, while the ones with high density sink and stay at the bottom of the sea. Considering that an immigrant group is 50-80 people on average, it is inevitable that the pollution will reach quite serious dimensions. Migrants wait for a while at the departure points on the coast to go out to sea. This waiting period is sometimes due to the lack of suitable weather and sea conditions, and sometimes due to the presence of coast guard boats in the region. The garbage left by hundreds of immigrants on the beach is a major source of pollution.

In the research studies conducted, it was observed that the immigrants did not leave for up to 10 days due to the increase in the inspections of the Gendarmerie, the Coast Guard and the Police or due to the unsuitable weather and sea conditions. Therefore, it is difficult to keep daily data and thus monthly, quarterly and annual data were obtained. It has been observed that mass departures are made after periods when irregular migrants do not exit for a long time, and it is seen that sinking and loss of life are higher in such departures.

When the irregular migration incidents and the number of irregular migrants detected by sea in 2015-2016 are compared; it is seen that 37,130 irregular migrants were seized in 833 irregular migration cases in 2016, and 91,611 irregular migrants were seized in 2,430 irregular migration cases in 2015. In 2016, compared to 2015, the number of irregular migration cases decreased by $66 \%$ and the number of irregular migrants by $60 \%$. As stated in other reports, the main reason for this decline is the developments in the first quarter of 2016 (the agreement reached between Turkey and the EU on 18 March 2016 on the issue of "taking back the immigrants who crossed 
the Greek Islands via Turkey", support activities of NATO and Turkish Naval Forces, the closure of the Macedonian border, etc.). However, it is considered that the initiation of NATO constituents in the Aegean Sea has a very limited contribution to this decrease.

Moreover, it has been seen that the measures taken in places where irregular migration incidents occur intensively with the Operation Aegean-Hope in the Aegean Sea and the Operation Safe-Med in the Mediterranean Sea, which were initiated and continued by the Coast Guard Command, were effective.

The most important reason for the use of the Aegean Sea in irregular migration incidents and attempts by sea, as in previous years, is considered to be the proximity of the Aegean islands to the Aegean coasts of Turkey.

When the means used in irregular migration incidents are examined; it has been observed that the vast majority of irregular migrants prefer to use rubber zodiac boats as in previous periods. Since the boat users are immigrants, zodiac boats are safer and easier to procure within the organizers. In addition, zodiac boats are the vehicles that cause the most environmental pollution. An irregular migrant group may use more than one zodiac boat for transit with repeated attempts to pass.

In particular, Syrian irregular migrants are not repatriated to their countries after they are seized, and they are not subject to any penal sanction other than administrative fines in our country. This situation causes Syrian irregular migrants to attempt to cross until the transition is successful, and environmental pollution caused by migrants is repeated.

Coastal areas are sensitive ecosystems. Irregular migrant activities, especially in coastal areas, cause an increase in marine litter pollution and adverse conditions. Being human-oriented and taking precautions accordingly is the primary priority in immigration activities, however, it is thought that a holistic approach will be beneficial, taking into account the damages experienced by the ecosystem in the region (Margules and Pressey, 2000; Dinerstein et al, 2000; Jennings et al, 1999; Myers et al, 2000). .

Irregular migrant mobility often causes crises between countries, as it has international affiliations. In this context, solution approaches are not effective either. It is thought that fast, solution-oriented and holistic results can be obtained by producing multi-participant and holistic solutions and legally regulating the approaches of countries to migrant activities. Especially in regions to be determined by scientific studies, research and aid activities can be organized together with nongovernmental organizations, and migrant activities can be limited by declaring special status protection zones. It is thought that undertakings can be brought under control with legal regulations and the establishment of executive mechanisms that will operate at speed. Nowadays, irregular migrant activities reveal problems that almost every country is directly or indirectly affected by. In this regard, it is thought that these activities, which affect human life in particular, can be controlled and the formation of marine litter can be reduced by better coordination with commissions and organizations to be established in the country and region.

\section{References}

Akgün, E. (2011). Yasa Dışı Göç Çerçevesinde TürkiyeAvrupa Birliği İlişkileri. İstanbul Üniversitesi Sosyal Bilimler Enstitüsü Kamu Yönetimi Anabilim Dalı, Doktora Tezi, 183.

Akkayan, T. (1979). Göç ve Değişme, İstanbul, s21

Çağlayan, S. (2008). "Göç ve Yoksulluk: Mutlak ve Doğrusal Olmayan Bir İlişki", (Ed.) Oktik, N., Türkiye'de Yoksulluk Çalışmaları, Yakın Kitabevi Yayınları, İzmir, ss: 301-324

Dinerstein, E., Powell, G., Olson, D.M., Wikramanayake, E. Abell, R., Loucks, C., Underwood, E. Allnutt, T., Wettengel, W., Ricketts, T., Strand, H., O'connor, S., Burgess, N. (2000). A Workbook for Conducting Biological Assessments and Developing Biodiversity Visions for Ecoregion-based Conservation, World Wildlife Fund. Washington D.C.

Düvell, F., Vollmer, M. (2009). Irregular Migration in and from the Neighbourhood of the EU. A comparison of Morocco, Turkey and Ukraine, 45p.

Ertekin, C. (2008). Cumhuriyet döneminde üniversite, bilim ve etik. Anadolu Kardiyoloji Dergisi, 8, 236240.

Gülersoy, A. E., Çelik, M. A., Sönmez, M. E. (2014). Tarsus Şehrinin Alansal Gelişimine (1985-2011) Ekolojik Bakiş. Electronic Turkish Studies, 9(2).

Güven-Lisaniler, F., Rodriguez, L., Uğural, S. (2005). Migrant sex workers and state regulation in North Cyprus. Paper presented at the Women's Studies International Forum.

Jennings, M., Mosesso, J., Scott. J.M. (1999): GAP: The Next Ten Years, Gap Analysis Bulletin, 8; 6-8.

Katsanevakis, S. (2015). Illegal immigration in the eastern Aegean Sea: a new source of marine litter. Mediterranean Marine Science, 16, 605-608.

Macionis, J.J. (2012). Nüfus, Kentleşme ve Çevre, (Çev.) Eroğlu, T., Sosyoloji, Nobel Yayıncılık, Ankara, ss: $566-597$.

Margules, C.R., Pressey, R.L. (2000). Systematic conservation planning, Nature, 405; 243-253.

Myers, N., Mittermeier, R.A., Mittermeier, C.G., Da Fonesca, G.A.B., Kent, J. (2000). Biodiversity hotspots for conservation priorities, Nature, 403; 853858.

Republic of Turkey Ministry of Interior Turkish Coast Guard Command (TCGC) (2021). Irregular Migration 
Statistics. Retrieved $06 \quad$ Nov 2021. https://en.sg.gov.tr/irregular-migration-statistics

Republic of Turkey Ministry of Interior, Presidency of Migration Management (PMM) (2021). Retrieved 06 August 2021. Irregular Migration Statistics https://en.goc.gov.tr/irregular-migration

Sever, H., Sever, M. (2013). Avrupa Birliği ve Türkiye Ekseninde Yasadışı Göç ve İltica Paradoksu: Domino Etkisi Sonrası Yaşananlar. Turkish Journal of Police Studies / Polis Bilimleri Dergisi . 2013, Vol. 15 Issue 2, p85-108. 24p

Thorns, D. C. (2004). Kentlerin Dönüşümü, Kent Teorisi ve Kentsel Yaşam, (Çev.) Nal, E. Nal, H. Soyak Yayınları, İstanbul.

Ülker, D., Ergüven, O., Gazioğlu, C. (2018). Socioeconomic impacts in a Changing Climate: Case Study Syria, International Journal of Environment and Geoinformatics, $\quad 5(1), \quad 84-93, \quad$ doi.10.30897 /ijegeo.406273 